Paideusis

\title{
Lawrence Kohlberg: Consensus and Controversy (Sohan Modgil and Celia Modgil (Eds.))
}

\section{William J. Hague}

Volume 3, Number 1, 1989

URI: https://id.erudit.org/iderudit/1073405ar

DOI: https://doi.org/10.7202/1073405ar

See table of contents

Publisher(s)

Canadian Philosophy of Education Society

ISSN

0838-4517 (print)

1916-0348 (digital)

Explore this journal

Cite this document

Hague, W. (1989). Lawrence Kohlberg: Consensus and Controversy (Sohan Modgil and Celia Modgil (Eds.)). Paideusis, 3(1), 11-17.

https://doi.org/10.7202/1073405ar 


\section{Review Article}

Modgil, Sohan and Modgil, Celia (Eds.) Lawrence Kohlberg: Consensus and Controversy (Philadelphia and London: Falmer Press, 1986). 569 pages. Hardback: $\$ 63.00$ (U.S.)

Debate as a strategy of learning among scholars has, regrettably, passed out of fashion. Instead we have an academic world that meets at conferences where "papers" are read, followed usually by a few "questions" which are "answered" by the presiding "expert". Often the exciting academic development takes place in the "smoke-filled rooms" upstairs in the hotel where, with jackets off and ties loosened, the presenters address the issues sharply, keenly, in a stimulating atmosphere of challenge and controversy. Rarely do the masses of attendees, still searching in the lobby for the next "big-name" session, get a chance to observe scholarly exchange at its most exciting and most productive.

To the extent that paper and print can do it, Modgil and Modgil have given us in this volume, an opportunity to be at least observers in that "smokefilled room," catching the excitement of ideas in conflict and getting involved in the confluence that comes from it. The result is a book not merely interesting to read, but one full of new insights from a myriad of perspectives into the work of one of the most important and controversial psychologists of our times-Lawrence Kohlberg.

Before reviewing this volume, it would help to put it in the context its ambitious editors and publishers see for it. Lawrence Kohlberg: Consensus and Controversy is Volume I of a five volume series entitled "The Falmer International Master-Minds Challenged" which debates the ideas of Eysenck, Chomsky, Jensen, and Skinner. Each volume follows a format which one must admire not only for its imaginativeness but for its ambition. It is a unique approach, valuable for two reasons. Firstly, each volume promises an article from the Master-mind himself, expressing his latest thinking and his reaction to the articles in the book. Secondly, the debate format provides an opportunity for selected experts to present theoretical analysis, sometimes supported by research. The debaters have been paired, according to their expertise and orientations, in pro and con positions on particular aspects of the master's position. The paired contributions have been exchanged, allowing for refutation of each other, and, in some cases, a meeting of minds. All of this has been püblished in what one can imagine from afar as an extended editorial nightmare. But the imagination, patience, and editorial expertise of Modgil and Modgil have paid off for us readers who can have in hand a volume which highlights the issues still unresolved, shows where consensus is growing, and sustains an inquiry into how each theory is seen in relation to a range of areas of knowledge. How this whole editorial idea was carried out in relationship to Lawrence Kohlberg and how successfully it was done will be the substance of this review.

To accomplish their goals, the editors recruited twenty eight scholars to comment on Kohlberg's work. Paired off in their pro-con positions, they address fourteen areas. 
Moral Philosophy--Robert Carter and Don Locke

Developmental Psychology \& Moral Philosophy--Dwight Boyd and Harvey Siegel

Moral Psychology--Olivera Petrovich and Peter Tomlinson

Moral Judgment \& Moral Action--Peter Kutnick and Roger Straughan

Moral Development \& Ego Development--Robert Kegan and Jane Loevinger

Morality, Reason and Emotions--Charles Bailey and John Martin Rich

Moral Education--John Wilson and Edmund Sullivan

Moral Curriculum: James Leming--David Gordon

Religious Education: Marion Smith--Brian Gates

Social Reasoning: R. Enright, D. Lapsley, L. Olson--Lea Pearson

Moral Reasoning and Political Issues: Helen Weinreich-Haste--John

Broughton

Theological Epistemology: Mary Marks Wilcox--Donald Joy

Cross-Cultural Morality: Carol Pope Edwards--Ian Vine

Moral Research Methodology: James Rest--Charles Evans

A glance at the list of authors indicates the country of origin of the book, England, from which many of the authors have been recruited. The editors themselves are British. Sohan Modgil is a Reader in Educational Research and Development at Brighton Polytechnic, while Celia Modgil is Senior Lecturer in Educational Psychology at the University of London. The United States and, to some extent, Canada are represented, but (with one exception, Israel) nothing appears from outside these parts of the English-speaking world. Perhaps this is appropriate to Kohlberg's major sphere of influence, but the book probably seems at times limiting to a universal view when, for example, in covering a topic such as Religious Education both "debators" are chosen from England with its unique background in this area. Regrettably, the editors do not provide us with a biographical sketch of each contributor beyond a statement of their place of employment. The reader is left to search for implications of this in the authors'. words and references.

\section{Kohlberg's Contribution}

Where does one start to review such a massive work as the Modgils have given us? With so many topics covered and such a diversity of opinion within them, one could start reading this book at almost any place one's own interests pointed them. Perhaps for reviewing purposes, the place to begin is not at the beginning, but with the concluding chapter where Kohlberg offers his own views in a response to some of the contributors.

His first reaction supplements what we have already noted in simply skimming the table of contents "... except for Boyd and Carter, the chapters in this volume reflect no awareness of European, especially German, responses to my theory ..." (p. 485). Habermas greatly influenced Kohlberg's most recent ideas; it is regrettable that no major recognition is given to this in the editors' structure of the volume. Kohlberg also laments the fact that not all his recent writings were in the hands of all the authors, especially the complete Volume II of his major trilogy. This lapse is understandable considering the date of publi- 
cation and the time-consuming task of compiling the Modgils' work. But it seems Kohlberg is crying a legitimate "foul" when he indicates that "much of my theoretical writing responded to in this volume was published in the early 1970's"' (p. 485).

Kohlberg tries to make up for these deficiencies by reviewing the basics of his theory and outlining in his own chapter more recent developments. But there are deficiencies even in this: one cannot help but be disappointed when Kohlberg, after spending page after page quoting from others' writings (some of which appear in other chapters of this same volume and can be read there in larger print) opts out by saying, "Unfortunately time and space prohibit my commenting on political and theological issues raised by my theory. Given these restrictions, I will also keep my remarks on education brief' (p. 542). As a rejoinder to a book which does give considerable notice to these important issues, less repetition of other's statements and more of the master's mature thinking would have been precious. Instead we get pages of tables explaining the basics of his six moral stages, all of which he has published before and most of which can be found even in undergraduate developmental psychology textbooks. One can, by the way, understand why so many textbooks list these as "The Six Moral Stages" as though Kohlberg had some God-like capacity to carve them in stone for the guidance of future generation. If the title "Kohlberg's Moral Stages" were used instead, it would admit the realistic possibility of alternative approaches. Modgil and Modgil must have accepted these great blocks of print unedited from Kohlberg allowing such phrases as "In chapter 3" (meaningless in the present context) to slip through. The disappointment at not getting more of the advanced thinking of Kohlberg at a time when we know he was turning some important philosophical corners is enhanced by the glimmers of what might have been flash across the pages in statement such as:

In my earlier writing I claimed that a deontological justice ethic was 'higher' or better than a utilitarian ethic. In attenuating the claim for Stage 6, I no longer take this position as one which could be clearly argued, in light of the formal similarities possible for each type of ethic. (p. 521)

Statements such as this and others which we will review made in the context of his discussion of the extent to which he (and Habermas) would accept certain forms of relativism leave one hungry. for more of the mature, reflective Kohlberg and less of his old tables and lengthy quotations from other people. It is not that Kohlberg's chapter is wanting in content, it is only that in his response to a definitive volume devoted entirely to him and his ideas, so many opportunities were missed in this final chapter, which we know now is token of the final chapter of his life.

\section{The Debaters' Contributions}

Now, let me turn to some comments on the articles by the debaters: one recent area of challenge to Kohlberg is conspicuous by its absence from the table of contents--the issue of the "ethic of care and responsibility" and related issues of women's moral thinking. These points are not absent from the book, as a glance at the indices indicates, but they were not, we must suppose, considered important enough by the editors to be highlighted in major sections. 
They are examples of some more current issues that are neglected. The task is left to Kohlberg himself to update the most recent issues, and this is regrettable. A "debate" section on these current issues would have given a more balanced view.

The Carter-Locke debate with which the book begins centers at Carter's instigation on the issue: "Does Kohlberg avoid relativism?" Carter attempts to clarify the term 'relativism' used he feels all too loosely by Kohlberg the philosopher, who moved, according to Carter, closer to one major form of relativist thought: hermeneutic methodological relativism. Carter says "His new ally, Habermas, is not only unable to save him from the philosophic vagaries of relativism ... but takes him into the very thick of the debate" (p. 19). Locke, on the other hand, although he pays tribute to Kohlberg's attempts to combine philosophy and psychology, is not quite so impressed by the philosophic Kohlberg, and comes to the conclusion that Kohlberg has provided an explanation of cultural relativism but not a refutation of it. Locke explores the 'is-ought' problem by pointedly criticizing the circularity of Kohlberg's arguments that a higher stage is necessarily a better stage. Carter in his rejoinder highlights the cosmic perspective of Stage 7, emphasizing the proviso that the impartiality of the view of the whole must be infused with love, or caring. He commends Locke for noting that Kohlberg seemed to be adding at Stage 7 what should have been present in the system all along: caring. "Had Kohlberg been clearer in his treatment of the place of caring-feeling-compassion in his theory, he would likely have been able to chart the increasing capacity for genuine fellow- feeling together with the more abstract and cognitive skills ..." (p. 40). Locke replies to Carter by labelling this as 'perspectivism' and reduces Carter's richer concept of the cosmic perspective to mere moral opinion, thereby lending support to Carter's previous contention that Locke fails to understand the concept.

Locke adds to the debate at this point an interesting postscript, made necessary by "the inevitable delay between writing and publication (which) has meant this chapter was out of date before it even appeared" (p. 42). It is an updating of his previous comments in the light of Kohlberg, Levine and Hewer's Moral Stages: a Current Formulation and a Response to Critics (1983). Locke rightly praises this work for its substantiveness and clarity when compared with some earlier Kohlberg writing, and acknowledges that this significant publication contains many key modifications of former positions, including a begrudging acknowledgement of Carol Gilligan's work, and a major attempt by Kohlberg to reverse his system of deriving 'ought' from 'is'. An attempt which Locke considers a failure. But Locke says "Reading between the lines, what seems to have happened is that Kohlberg has only recently recognized what the Naturalistic Fallacy ... actually is, and has thought, 'Good Heavens, I can't be doing that!' " (p. 42). An unfair criticism perhaps but another thoughtprovoking corner of this thoroughly thought-provoking volume, and an example of the difficulties of keeping such a major editorial task up to date.

Dwight Boyd in the subsequent chapter also focuses on the relationship of 'is' and 'ought'. Judging by the positive comments Kohlberg makes about this article (e.g., "Boyd's chapter is central in this volume." (p. 505) and the lengthy quotes he lifts from it, Boyd's contribution would appear to be the one looked upon most favourably by Kohlberg. As such, it deserves special attention. 
Boyd is clear and systematic in his attacks on insupportable interpretations of what Kohlberg states on the 'is-ought' issue and he reaches beyond Kohlberg to give his own suggestion for the most positive interpretation of the Master. Boyd, like Locke and Carter, acknowledges Kohlberg's endeavours in the double realms of moral philosophy and developmental psychology, but, unlike the previous authors, he is quicker to explain away the difficulties. He explicitly sets out to "engage in some exegesis of Kohlberg's statements ... (but) ... due to the vagueness and unfinished nature of Kohlberg's thinking on this topic, this exegesis will very soon extend into the task of trying to articulate possible lines of thought which seem to be the promising directions of interpretation of Kohlberg's intentions, even if in the end it goes beyond what Kohlberg has clearly said"' (p. 45).

Boyd structures his chapter around four possible, but rejectable interpretations of how Kohlberg handled the 'is-ought' controversy, hitting on a fifth plausible "complementarity" approach. The background to this can be seen (if one keeps a finger in the back pages of the volume) in Kohlberg's comments on the Boyd article:

As Boyd elaborates, I (Kohlberg, 1984, Ch. 3) accept a distinction made by Habermas (1983) between the 'performative' attitude of dialogic arguments of professional moral philosophers ... and the 'objectivating' attitude of professional psychologists .... The human being as philosopher is attempting to justify the rightness of moral judgments or principles. The human being as psychologist is attempting to establish the empirical truth of propositional explanations of moral judgment and action. As a result of this distinction I (Kohlberg, Levine and Hewer, 1983) followed Habermas (1983) in abandoning the ultimate identity ... of psychological explanations of why people move from stage to stage and of moral philosophic justifications of the greater adequacy of a later stage over its predecessor .... Instead I have retreated to what Habermas calls the 'complementarity thesis', ... which depends on the ... assumption that my theory is a 'rational reconstruction of moral ontogenesis.' (p. 507)

Boyd summarizes his conclusions this way: "... the developmental psychologist is required not only to 'interpret' how a person is making and evaluating 'ought' claims, but also to 'interpret' why a person would change their way of making and evaluating 'ought' claims and why this change is systematic in a particular direction" (p. 60). Boyd claims that this theory has a unique strength--the view of the subject as the constructive moral agent. He concludes, "It is ... this bi-dimensional, correlative adoption of the performative attitude by the developmental psychologist that best explains what lies behind the 'complementarity thesis' intended by Kohlberg" (p. 61). He sees it as the beginning of a bridge across the 'is'-'ought' gap at the border between developmental psychology and moral philosophy.

Kohlberg accepts Boyd's bridge, asserting that it is implicit in his previous work, but attempts to clarify it further, extending the bridge metaphor into a spiral connecting philosophy and psychology (p. 510). Siegal in his chapter and Wilson in his, Kohlberg maintains, defend the moat between philosophy and psychology, giving little room for psychology to address the 'is'-'ought' issue. Kohlberg says:

In contrast, Boyd and I defend the complementarity thesis between moral 
philosophy and psychology in the task of defining moral reasoning goals of education. This is because, in addition to the meta-ethical assumptions guiding the empirical study of ontogenesis, there have been normative ethical assumptions as to the nature of more 'rational' or more 'moral' judgment and reasoning. (pp. 511-512).

Kohlberg then goes to great length (and interminable quotations) to justify his views against the background of his previous commitments. In this sense his chapter is largely an apologia and backward-looking, yet he tantalizes the reader by merely suggesting new directions. After noting that the Habermas influence helps extend the structural approach to include non- justice defined aspects of relationships as proposed by the care orientation, he slips in what must surely be a future-oriented sentence: "In this way, the Habermas project suggests an integration of our justice stages and the levels of care suggested by Gilligan and her colleagues" (p. 541). It is a sentence worthy itself of considerable exegesis.

Harvey Siegal presents a relatively mild contra view which Boyd later praises as, “... the only sustained attempt that I know of (besides my own) to interpret and evaluate Kohlberg's claims about the relationship between moral philosophy and developmental psychology" (p. 79). Siegal accuses Kohlberg of placing too much faith in psychology, maintaining that "empirical research is impotent with respect to the justification of education intervention" (p. 74). He maintains that neither Kohlberg nor anyone else can justify judgments of moral adequacy by appeal to the facts of development. Boyd replies by maintaining that, far from an impotency metaphor, there is a generative potential in an integration of philosophy and psychology. Siegal replies by saying he is not yet convinced, but encourages Boyd to further develop a positive interpretation of the complementarity thesis, congratulating him in the end "for his effort to make sense, in a novel way, of Kohlberg's exceedingly obscure position ..." (p. 83). Thus the debate goes on, this one being prototypical of what is to follow throughout the book.

Thus far this review has centered on those chapters which cluster around questions of the relationship of philosophy and psychology. This is partly because of the fundamental nature of the issues, partly because Kohlberg himself paid great attention to them, and partly because of the quality of the chapters that address them. The editors have located them at the beginning of the book. Some later chapters deserve highlighting. One is Olivera Petrovich's chapter on moral autonomy. While some other chapters are obtuse and wordy, Petrovich's is outstanding in its clarity and readableness. Besides defining a variety of conceptions of autonomy, Petrovich quickly gets to the core of the relationship of religion and morality, especially in a Kohlbergian context, by bringing our attention back to the importance of an aspect of Kohlberg's thought that tends to be neglected--the mysterious Stage 7. For many perhaps Stage 7 is literally "too far out" from the mainstream of Kohlberg. Yet Petrovich reminds us of its relevance to a fuller understanding of all of Kohlberg's stages. It is true that Kohlberg had mixed (maybe confused) feelings about the relationship of religion and morality, but Petrovich goes so far as to claim that Kohlberg worked from the assumption, "that moral development chronologically precedes religious development so that the latter has nothing to contribute to the former" (p. 101). Petrovich, in concluding her chapter, points to a Kohlbergian tendency that I have already indicated in reviewing the present volume--his penchant for dropping "clues" of where others might go with his ideas Paideusis 
One concludes a review of a massive and diversified book such as this with feelings of regret in passing over issues such as the relationship of moral judgment and moral action and "Morality, Reason and Emotions" and in passing over names such as Kegan, Loevinger, Sullivan, and Rest. But one may perhaps borrow a phrase for which Kohlberg was criticized earlier in this review: "Time and space do not permit ...."

But, pursuing own subjective reactions to the other contributions, I would like to single out Helen Weinreich-Haste's chapter on Kohlberg's contribution to political psychology as being a pleasure to read. I would also like to give credit to Roger Straughan not only for the content of his article but for breaking free from the rather stodgy academic mould that shaped so many titles in this book. Taking a phrase from a session at a memorable Leicester conference, he entitled his contribution, "Why Act on Kohlberg's Moral Judgments? (Or How to Reach Stage 6 and Remain a Bastard)."

Overall, this is an outstanding, monumental volume. It is certainly not an "introduction" to Kohlberg. It is rather a book intended for the serious scholar with some background and appreciation of the issues. It is a work that one may well want to selectively pick one's way through. It is also a book one will enjoy reading for the sake of the intellectual stimulation of intriguing controversy at its best, and one will keep it as a truly outstanding collection of eminent scholars who have attempted to understand a great figure in the history of psychology from a variety of perspectives. This book will have served its purposes well if scholars will take up the hints and "clues" Kohlberg leaves in it, and pursue them in the same spirit that inspired its contributors and editors. It is, above all, a tribute to the man, Lawrence Kohlberg, to the richness of his thought which inspires such controversy and consensus and to the legacy of challenges he left us.

William J. Hague, Department of Educational Psychology, University of Alberta 